\title{
Pelatihan dan Pendampingan Jaringan Komputer dengan Mikrotik di Pondok Pesantren Modern Terpadu Dr. Muhammad Natsir Alahan Panjang Kabupaten Solok
}

\author{
Heru Dibyo Laksono, Reri Afrianita, Mumuh Muharram, dan Novizon \\ Fakultas Teknik, Universitas Andalas, Kampus Limau Manis, Padang, 25163. Indonesia \\ e-mail: herudibyolaksono@eng.unand.ac.id
}

Keywords: assistance, computer network, Mikrotik, Modern Islamic Boarding School

Kata Kunci: jaringan computer, Mikrotik, pendampingan, pondok pesantren

\begin{abstract}
Training of Computer network using Miktrotik at the Integrated Modern Islamic Boarding School of Dr. Muhammad Natsir at Alahan Panjang is one of the solutions to overcome the problem of the effectiveness and efficiency computer user. The training was started by a field survey to laboratory of the information and communication technology (ICT) at the School. In this survey, discussions were held on what problems are very important and get priority to find solutions in increasing the effectiveness and efficiency of computer use at the School. The results of the survey agreed that computer network training with Mikrotik would be held in order to increase the effectiveness and efficiency of computer use on it. The second activity was the preparation of computer network training with Mikrotik. Preparation was carried out in the form of discussions with teammates to determine materials and methods that were more efficient and effective in the implementation of computer network training with Mikrotik at the Information and Communication Technology (ICT) laboratory. The results of the discussion agreed that the training would be provided in the form of presentations and hands-on practice. The third activity was the implementation of computer network training with mikrotik. This training was provided for 2 days, namely Saturday and Sunday. The first day was done by shared knowledge about the basics of computer networks and Mikrotik. The second day, students did a computer network training with Mikrotik. The fourth activity was the evaluation of computer network training activities with Mikrotik, to evaluate the activities that have been carried out and to obtain suggestions and input for future improvements.
\end{abstract}
ABSTRAK
Kegiatan pelatihan jaringan komputer dengan Mikrotik di Pondok Pesantren Modern Terpadu Dr. Muhammad Natsir Alahan Panjang ini merupakan salah satu solusi yang diberikan untuk menjawab permasalahan efektifitas dan efisiensi penggunaan komputer di Pondok Pesantren. Kegiatan pelatihan dimulai dengan survei lapangan ke laboratorium teknologi informasi dan komunikasi (TIK) Pondok Pesantren Modern Terpadu Dr. Muhammad Natsir Alahan Panjang. Pada kegiatan survei ini dilakukan diskusi mengenai permasalahan - permasalahan apa saja yang sangat penting dan mendapatkan prioritas untuk dicarikan solusi dalam peningkatan efektifitas dan efisiensi penggunaan komputer Pondok Pesantren Modern Terpadu Dr. Muhammad Natsir Alahan Panjang. Hasil dari survei disepakati bahwa harus diadakan pelatihan jaringan komputer dengan Mikrotik dalam rangka peningkatan efektifitas dan efisiensi 
penggunaan komputer di Pondok Pesantren. Kegiatan kedua adalah persiapan pelatihan jaringan komputer dengan Mikrotik. Persiapan dilakukan dalam bentuk diskusi dengan rekan satu tim untuk menentukan materi dan cara yang lebih efisien dan efektif dalam pelaksanaan pelatihan jaringan komputer dengan Mikrotik di laboratorium TIK. Hasil dari diskusi disepakati bahwasanya pelatihan diberikan dalam bentuk presentasi dan praktek langsung. Kegiatan ketiga adalah pelaksanaan pelatihan jaringan komputer dengan Mikrotik. Pelatihan ini telah dilaksanakan selama 2 hari yaitu hari Sabtu dan Minggu. Materi pengetahuan tentang dasar - dasar jaringan komputer dan mikrotik diberikan pada hari pertama, diikuti dengan praktek pada hari kedua. Kegiatan keempat adalah evaluasi kegiatan pelatihan jaringan komputer dengan mikrotik, dengan tujuan untuk melakukan evaluasi kegiatan yang sudah dilakukan dengan tujuan untuk memperoleh saran dan masukan untuk perbaikan kedepannya.

\section{PENDAHULUAN}

Pesantren Dr. Muhammad Natsir adalah satu dari beberapa pondok pesantren modern yang ada di Sumatera Barat. Pesantren yang bergerak di bidang pemberdayaan ekonomi pertanian dalam rangka otonomi finansial pesantren ini terletak di Batubagiriak kenagarian Alahan Panjang Kabupaten Solok. Pesantren ini lahir dari keprihatinan beberapa orang guru Sekolah Menengah Atas (SMA) Alahan Panjang terhadap siswa-siswa mereka yang sering terlambat membayar uang sekolah (SPP). Setelah dipelajari lebih jauh, kondisi tersebut ternyata disebabkan oleh faktor kemiskinan yang jika dibiarkan tidak tertutup kemungkinan dapat mengganggu hak-hak anak untuk mendapat pengajaran. Karena itu, muncul inisiatif dari beberapa orang guru Sekolah Menengah Atas (SMA) Negeri Alahan Panjang untuk mendirikan sebuah sekolah yang mampu mengatasi kesulitan masyarakat miskin untuk mendapatkan pendidikan yang layak. Sejak tahun 1992, rencana mendirikan sekolah tersebut sudah mulai dibicarakan dengan berbagai komponen dan tokoh masyarakat Batubagiriak Kenagarian Alahan Panjang. Pertemuan pertama diadakan di Mushalla Nurul Iman, yaitu mushalla masyarakat Batubagiriak yang hingga saat ini masih digunakan oleh Pondok Pesantren Dr. Muhammad Natsir sebagai tempat belajar murid-murid madrasah diniyah awaliyah (MDA). Respon masyarakat Batubagiriak Alahan Panjang sangat positif terhadap rencana pendirian sekolah yang merupakan cikal bakal pesantren tersebut. Hal ini terlihat dari kerelaan hati mereka memberikan harta benda berupa uang, emas, binatang ternak dan beberapa lahan di sekitar mushalla Nurul Iman sebagai modal bagi pendirian pesantren. Setelah pertemuan pertama tahun 1992 hingga dimulainya pembangunan Pondok Pesantren Dr. Muhammad Nasir, para pendiri dan tokoh masyarakat Batubagiriak mulai mengintensifkan kegiatan keagamaan di Mushalla Nurul Iman berupa pengajian satu kali dalam seminggu dengan tujuan untuk memberi pemahaman kepada masyarakat tentang pentingnya pendidikan, terutama pendidikan agama terhadap generasi muda. Para ustadz yang mengisi pengajian itu didatangkan dari berbagai daerah di Sumatera Barat, seperti Solok, Padang Panjang, Bukittinggi dan Padang.

Pembangunan Pondok Pesantren Dr. Muhammad Natsir dimulai dengan pembentukan yayasan yang bernama Yayasan Nurul Iman, yaitu nama yang disesuaikan dengan nama mushalla yang menjadi pusat aktivitas keagamaan masyarakat Batubagiriak Kenagarian Alahan Panjang. Yayasan tersebut memiliki visi menjadi yayasan terbaik, terkemuka, terpercaya, modern dan membanggakan masyarakat Batubagiriak, Alahan Panjang. Adapun misi yang diusung oleh Yayasan Nurul Iman adalah pertama, menyelenggarakan amal usaha sosial yang profesional, berkualitas dan mampu mengantarkan santri dan masyarakat kepada kesejahteraan lahir-batin. Kedua, 
menyelenggarakan pendidikan akademik yang Islami, profesional, berkualitas dan mampu menjawab tantangan zaman. Ketiga, menciptakan pembinaan anak didik dalam pesantren untuk pengembangan ilmu pengetahuan dan teknologi, berakhlak mulia dan berguna bagi umat dan negara. Keempat, membangun dakwah dalam rangka terciptanya masyarakat yang Islami. Kelima, membangun amal usaha ekonomi produktif yang berhasil guna, berfungsi guna, dan bernilai guna bagi kesejahteraan umat. Keenam, melaksanakan kerja sama dengan berbagai lembaga dan institusi lain, pemerintah dan swasta dalam upaya meningkatkan mutu yayasan, pendidikan dan lapangan kerja, serta pembinaan dengan stakeholder lainnya. Sarana pendidikan pertama yang dibangun sebagai tahap awal bagi pendirian pesantren adalah mesjid Nurul Iman dan panti asuhan yang sekarang ini berlokasi di komplek Yayasan Nurul Iman yang menaungi pendidikan Pesantren Dr. Muhammad Natsir. Pada tahun yang sama dimulai pula pembangunan gedung yayasan, sekolah, asrama dan sarana lainnya yang menunjang proses pendidikan. Pemberian nama pesantren didasarkan atas usulan beberapa tokoh masyarakat yang ingin mengabadikan nama salah seorang ulama dan tokoh nasional yang berasal dari Alahan Panjang, yaitu Dr. Muhammad Natsir. Selain keinginan mengabadikan nama besar Dr. Muhammad Natsir, para pendiri pesantren dan tokoh masyarakat Alahan Panjang juga terinspirasi oleh semangat perjuangan tokoh tersebut yang pada masa berikutnya sangat mewarnai misi pendidikan pesantren, yaitu pertama, memajukan pendidikan agama Islam seperti yang dicita-citakan oleh Dr. Muhammad Natsir; kedua, memajukan pengembangan ilmu pengetahuan dan teknologi; ketiga, membangun masyarakat yang Islami; dan keempat, melahirkan santri-santri mujahid dakwah yang memiliki keahlian dan keterampilan.

Yayasan Nurul Iman saat ini mengelola tiga tingkatan pendidikan atas nama pondok pesantren terpadu Dr. Muhammad Natsir, yaitu pendidian anak usia dini (PAUD dan TK), madrasah tsanawiyah (MTs) dan sekolah menengah atas (SMA). Ketiga tingkatan pendidikan tersebut terletak pada dua lokasi dengan jarak yang tidak berjauhan di Batubagiriak, Kenagarian Alahan Panjang. PAUD dan TK bertempat di komplek yayasan Nurul Iman. Selain itu, komplek yayasan Nurul Iman juga terdiri dari bangunan lainnya, yaitu mesjid, mushalla, asrama putra-putri, panti asuhan dan dapur pesantren. Sementara, Madrasah Tsanawiyah dan Sekolah Menengah Atas (SMA) terletak di sebelah Barat komplek yayasan dengan jarak sekitar 500 meter. Komplek yayasan Nurul Iman terletak di tengah-tengah perkampungan penduduk Batubagiriak, Kenagarian Alahan Panjang. Sementara Mesjid Nurul Iman yang terdapat di lingkungan yayasan tersebut masih menjadi pusat kegiatan keagamaan masyarakat Batubagiriak. Secara geografis, madrasah tsanawiyah dan sekolah menengah atas (SMA) pondok pesantren terpadu Dr. Muhammad Natsir berada pada lokasi strategis dan mudah dijangkau oleh masyarakat karena terletak di pingir jalan Padang, Solok dan Muara Labuh. Di samping itu, Pondok Pesantren Dr. Muhammad Natsir juga berada di lokasi yang memiliki pemandangan alam yang indah. Sebelah timur, utara dan selatan kelihatan lahan pertanian masyarakat yang luas dan daerah perbukitan. Sebelah barat, tepatnya di depan pondok pesantren dengan jarak sekitar 1.5 kilometer kelihatan pemandangan danau di atas yang banyak dikunjungi oleh wisatawan demestik dan macanegara, terutama pada hari-hari libur.

Pondok Pesantren Dr. Muhammad Natsir Alahan Panjang juga dilengkapi dengan fasilitas - fasilitas pendukung untuk proses belajar mengajar (PBM) diantaranya ruang kelas, ruang majelis guru, laboratorium, perpustakaan dan sarana - prasarana teknologi informasi dan komputer (TIK). Selain itu perkembangan teknologi informasi dan komunikasi (TIK) disegala bidang tumbuh begitu pesat merambah dunia pendidikan dengan segala aspeknya menyangkut kebutuhan administrasi manajemen guru dan siswanya, sehingga hampir seluruh kegiatan kita tidak terlepas dari teknologi informasi yang semakin canggih ini khususnya komputer (Haryanto, 2018). Saat ini Pondok 
Pesantren Modern Terpadu Dr. Muhammad Natsir Alahan Panjang sudah mempuyai laboratorium teknologi informasi dan komunikasi (TIK) dengan jumlah komputer sebanyak 25 unit. Dalam penggunaanya komputer - komputer ini digunakan secara terpisah - pisah sehingga pemakaian menjadi kurang efektif dan efisien baik dari sisi tempat, waktu dan biaya. Dengan adanya pelatihan jaringan komputer dengan mikrotik ini diharapkan para peserta pelatihan bisa merancang dan implementasikan jaringan komputer di Pondok Pesantren Modern Terpadu Dr. Muhammad Natsir Alahan Panjang dengan harapan efektifitas dan efisiensi dari penggunaan komputer - komputer ini tercapai dengan baik.

Adapun beberapa permasalahan yang berkaitan dengan perkembangan teknologi informasi dan komunikasi (TIK) yang dihadapi oleh Pondok Pesantren Modern Terpadu Dr. Muhammad Natsir Alahan Panjang diantaranya adalah

- Perkembangan teknologi informasi dan komunikasi (TIK) yang berkembang pesat sedangkan pemanfaatan dan perkembangan teknologi informasi dan komunikasi (TIK) di Pondok Pesantren Dr. Muhammad Natsir Alahan Panjang sendiri masih jalan ditempat khususnya berkaitan dengan kemajuan teknologi jaringan komputer.

- Kemajuan teknologi informasi dan telekomunikasi (TIK) khususnya bidang teknologi jaringan komputer yang terus berkembang dengan tidak mengenal batas waktu, ruang dan jarak (Kurose, 2005), sedangkan di Pondok Pesantren Modern Terpadu Dr. Muhammad Natsir Alahan Panjang pemanfaatan jaringan komputer untuk peningkatan efektifitas dan efisiensi penggunaan komputer belum dilakukan secara baik dan benar.

Untuk itu dengan melibatkan tenaga akademis dari Program Studi Teknik Elektro Fakultas Teknik Universitas Andalas harus diadakan pelatihan jaringan komputer dengan mikrotik di Pondok Pesantren Modern Terpadu Dr. Muhammad Natsir Alahan Panjang. Kegiatan ini akan dilaksanakan di laboratorium teknologi informasi dan komunikasi (TIK) Pondok Pesantren Modern Terpadu Dr. Muhammad Natsir Alahan Panjang dengan pesertanya para guru - guru bidang studi teknologi informasi dan komunikasi (TIK), pengelola laboratorium teknologi informasi dan komunikasi (TIK) serta siswa - siswa sekolah menengah atas (SMA) Pondok Pesantren Modern Terpadu Dr. Muhammad Natsir Alahan Panjang. Dengan adanya kegiatan pelatihan jaringan komputer dengan mikrotik ini diharapkan akan memberikan pengetahuan kepada pada peserta pelatihan mengenai perancangan, implementasi dan pemanfaatan jaringan komputer dengan mikrotik (Mukti, 2020) untuk mendukung aktivitas pekerjaan sehari - hari di Pondok Pesantren Modern Terpadu Dr. Muhammad Natsir Alahan Panjang.

\section{METODE}

Berdasarkan permasalahan yang berkaitan dengan teknologi informasi dan komunikasi (TIK) khususnya jaringan komputer di Pondok Pesantren Modern Terpadu Dr. Muhammad Natsir Alahan Panjang disepakati bahwa kegiatan yang akan dilaksanakan adalah pelatihan jaringan komputer dengan mikrotik. Adapun prosedur kerja yang dilakukan adalah

1. Mengadakan survei lapangan ke Pondok Pesantren Modern Terpadu Dr. Muhammad Natsir Alahan Panjang.

2. Persiapan pelatihan jaringan komputer dengan mikrotik di laboratorium teknologi informasi dan komunikasi (TIK) Pondok Pesantren Modern Terpadu Dr. Muhammad Natsir Alahan Panjang.

3. Pelaksanaan pelatihan jaringan komputer dengan mikrotik.

4. Evaluasi kegiatan pelatihan jaringan komputer dengan mirkotik.

5. Pembuatan dan penyusunan laporan akhir. 
Kegiatan untuk program pengabdian ini akan difokuskan pada pelatihan jaringan komputer dengan mikrotik. Rencana kegiatan pelatihan ini akan dilaksanakan dalam waktu 2 hari yaitu pada hari Sabtu dan Minggu. Kegiatan pertama yang dilakukan adalah survei lapangan ke laboratorium teknologi informasi dan komunikasi (TIK) Pondok Pesantren Modern Terpadu Dr. Muhammad Natsir Alahan Panjang. Pada kegiatan survei ini dilakukan diskusi mengenai permasalahan - permasalahan apa saja yang sangat penting dan mendapatkan prioritas untuk dicarikan solusi dalam rangka peningkatan efektifitas dan efisiensi penggunaan komputer di Pondok Pesantren Modern Terpadu Dr. Muhammad Natsir Alahan Panjang. Hasil dari survei disepakati bahwa akan diadakan pelatihan jaringan komputer dengan mikrotik dalam rangka peningkatan efektifitas dan efisiensi penggunaan komputer di Pondok Pesantren Modern Terpadu Dr. Muhammad Natsir Alahan Panjang. Kegiatan kedua adalah persiapan pelatihan jaringan komputer dengan mikrotik. Persiapan dilakukan dalam bentuk diskusi dengan rekan satu tim untuk menentukan materi dan cara yang lebih effisien dan efektif dalam pelaksanaan pelatihan jaringan komputer dengan mikrotik di laboratorium teknologi informasi dan komunikasi (TIK) Pondok Pesantren Modern Terpadu Dr. Muhammad Natsir Alahan Panjang. Hasil dari diskusi disepakati bahwasanya pelatihan akan akan diberikan dalam bentuk presentasi dan praktek langsung. Kegiatan ketiga adalah pelaksanaan pelatihan jaringan komputer dengan mikrotik. Pelatihan ini akan dilaksanakan dalam waktu 2 hari yaitu hari sabtu dan minggu. Untuk hari pertama dengan materi pengetahuan tentang dasar - dasar jaringan komputer dan mikrotik (Mukti, 2020). Untuk hari kedua dengan materi praktek pelatihan jaringan komputer dengan mikrotik. Kegiatan keempat adalah evaluasi kegiatan pelatihan jaringan komputer dengan mikrotik. Kegiatan ini bertujuan untuk melakukan evaluasi kegiatan yang sudah dilakukan dengan tujuan untuk memperoleh saran dan masukan untuk perbaikan kedepannya. Evaluasi yang dilakukan meliputi materi pelatihan, cara penyampaian materi, tindak lanjut pelatihan dan sebagainya. Kegiatan terakhir adalah pembuatan dan penyusunan laporan akhir kegiatan.

Jenis luaran yang dihasilkan dari kegiatan ini adalah adanya peningkatan pengetahuan para peserta pelatihan dalam bidang teknologi informasi dan komunikasi (TIK) terutama dalam bidang jaringan komputer. Selain itu para peserta pelatihan mempuyai kemampuan untuk melakukan perancangan dan implementasi jaringan komputer di Pondok Pesantren Modern Terpadu Dr. Muhammad Natsir Alahan Panjang dan adanya buku panduan untuk untuk perancangan dan implementasi jaringan komputer dengan mikrotik ini.

\section{HASIL DAN PEMBAHASAN}

Kegiatan pelatihan jaringan komputer dengan mikrotik di Pondok Pesantren Modern Terpadu Dr. Muhammad Natsir Alahan Panjang ini dilaksanakan selama 2 hari bertempat di laboratorium teknologi informasi dan komunikasi (TIK) Pondok Pesantren Modern Terpadu Dr. Muhammad Natsir Alahan Panjang. Adapun peserta dari kegiatan ini adalah guru - guru bidang studi teknologi informasi dan komunikasi, pengelola laboratorium teknologi informasi dan komunikasi (TIK) dan siswa - siswa sekolah menengah atas (SMA) Pondok Pesantren Modern Terpadu Dr. Muhammad Natsir Alahan Panjang. Adapun materi dari kegiatan pelatihan ini adalah
a. Pengenalan peralatan dan sistem jaringan.
b. Pengenalan media antarmuka, protokol dan arsitektur jaringan.
c. Pengenalan tipe dan setting TCP/IP jaringan.
d. Pengertian dan pengenalan mikrotik dasar.
e. Skema jaringan mikrotik. 
f. Instalasi mikrotik di komputer.

g. Cek Koneksi jaringan.

Jaringan komputer kini telah diimplementasikan diseluruh organisasi perkantoran, bahkan di organisasi skala kecil sekalipun. Hal ini tentunya membuka peluang kerja yang besar, mengingat tidak semua pengguna komputer dapat membangun sebuah jaringan komputer yang benar-benar sesuai kebutuhan (Mulyanta, 2005). Pelatihan ini memberikan panduan bagi para peserta untuk melengkapi dan meningkatkan skill sehingga mampu memberikan teknikal support di bidang komputer dan networking, seperti penentuan software/hardware yang dibutuhkan dan serta perakitan dan instalasi komputer, konfigurasi jaringan serta perakitan dan instalasi jaringan komputer, hingga masalah troubleshooting seputar jaringan komputer.

Jaringan Komputer itu sendiri adalah kumpulan beberapa komputer yang dihubungkan satu dengan lainnya dengan menggunakan protokol komunikasi melaui media transmisi/media komunikasi sehingga dapat saling berbagi informasi, program dan penggunaan bersama perangkat keras (Syafrizal, 2020). Keuntungan adalanya jaringan komputer ini dimana penggunaan bersama peralatan, data, program dan informasi, sebagai salah satu media komunikasi tanpa pulsa dan terbentuknya sistim informasi yang terintegrasi secara lokal yang dikenal dengan istilah Local Area Network (LAN) (Winarno, 2013).

Jaringan Local Area Network (LAN) adalah bentuk jaringan komputer yang luas areanya sangat terbatas. Biasanya diterapkan untuk jaringan komputer rumahan, lab komputer disekolah dan kantor, dimana masing-masing komputer dapat saling berinteraksi, bertukar data dan dapat mengunakan peralatan bersama seperti printer dll. Beberapa keuntungan jaringan Local Area Network (LAN) adalah (Yovita \& Irawati , 2015)

a. Dapat saling bertukar file

b. Pengamanan data dalam bentuk backup dapat disimpan di beberapa komputer

c. Penggunaan peralatan seperti printer secara bersamaan

d. Sebagai media komunikasi antar penguna tanpa pulsa

e. Dapat dihubungkan dengan Internet sehingga seluruh komputer dalam jaringan dapat mengakses Internet

f. Sebagai media monitoring dan perawatan dengan mengunakan sistim remote.

g. Dapat dibuat sistim client server sehingga pengunaaan dan manajemen data terpusat

Beberapa dokumentasi dari pelatihan jaringan komputer dengan mikrotik di

Pondok Pesantren Modern Terpadu Dr. Muhammad Natsir Alahan Panjang ini diperlihatkan pada Gambar - Gambar berikut.

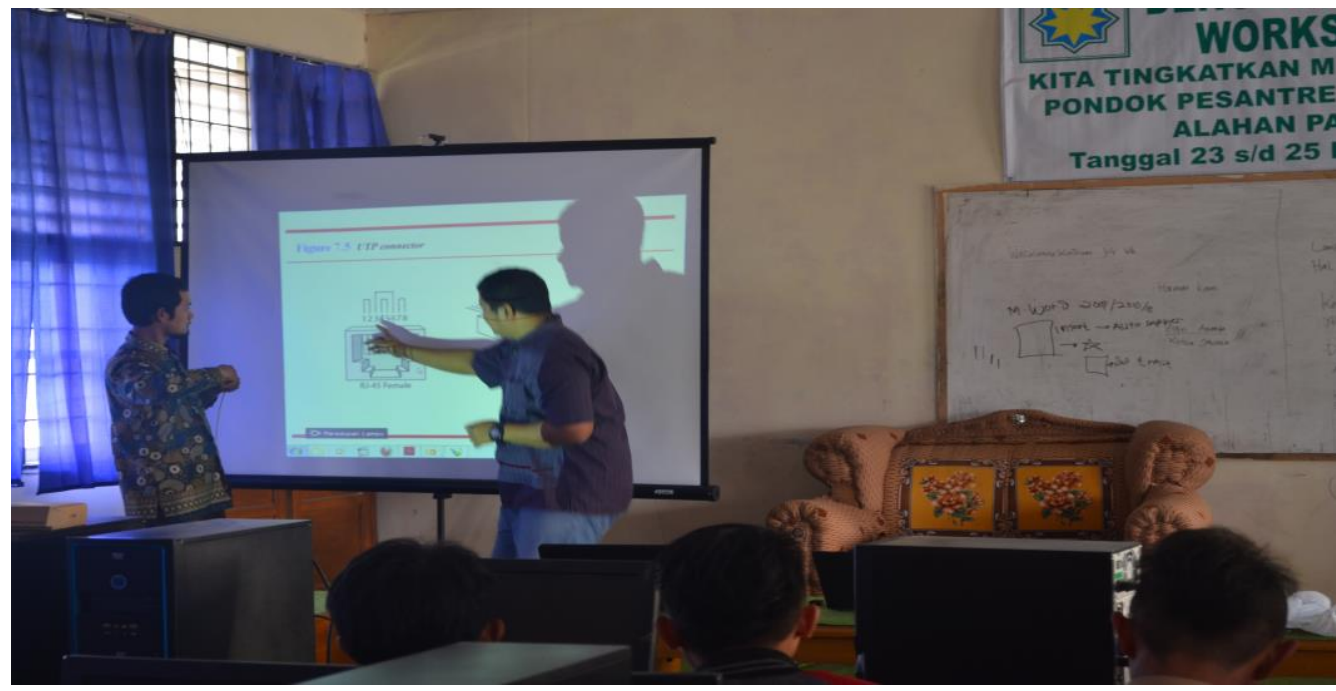

Gambar 1. Instruktur Memberikan Penjelasan Tentang Teori Jaringan Komputer 


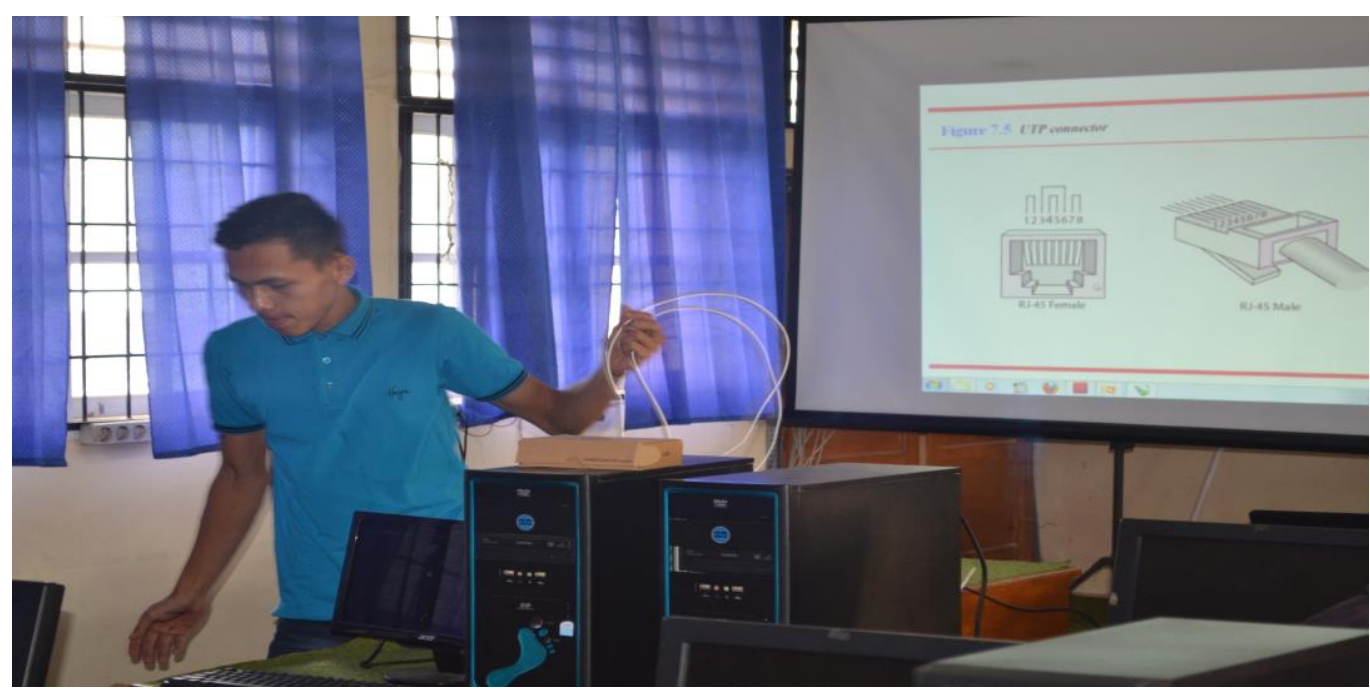

Gambar 2. Instruktur Mendemontrasikan Cara Membangun Jaringan Sederhana

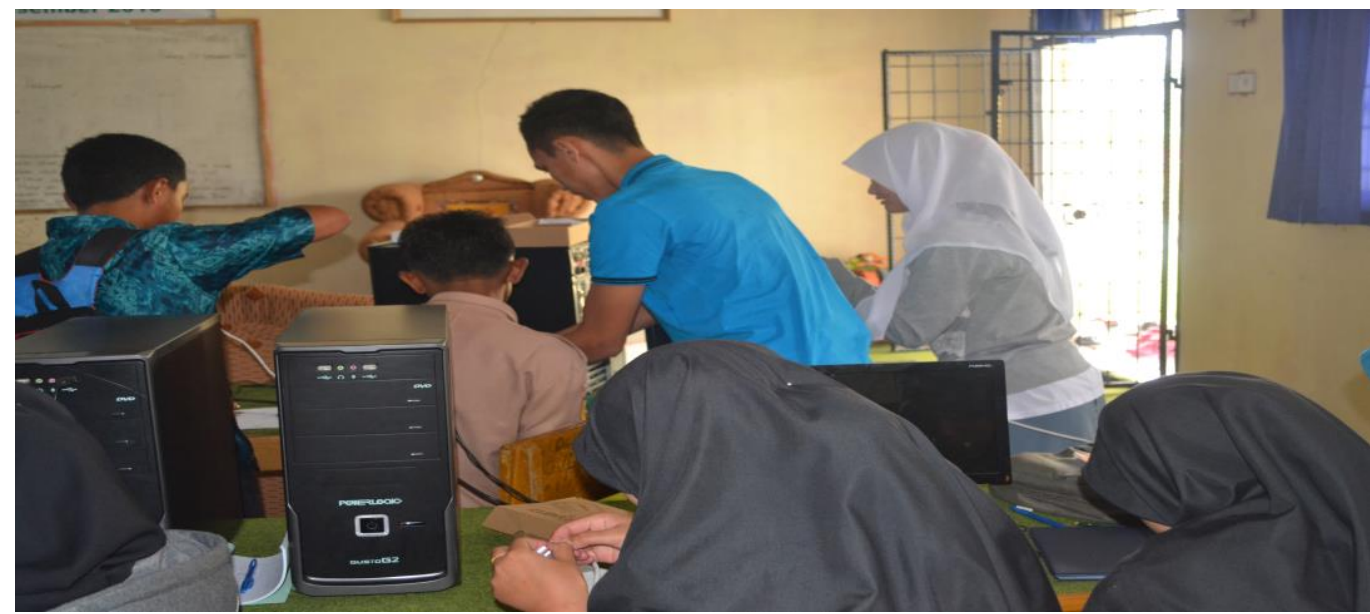

Gambar 3. Kegiatan Praktek Jaringan Komputer dengan Mikrotik

Selain itu dalam kegiatan ini juga dibagikan buku panduan kepada peserta pelatihan, guna memudahkan peserta untuk mengulang-ulang praktek ilmu yang sudah dibagikan oleh tim pengabdian. Adapun cover dari buku panduan diperlihatkan pada Gambar 4 berikut.

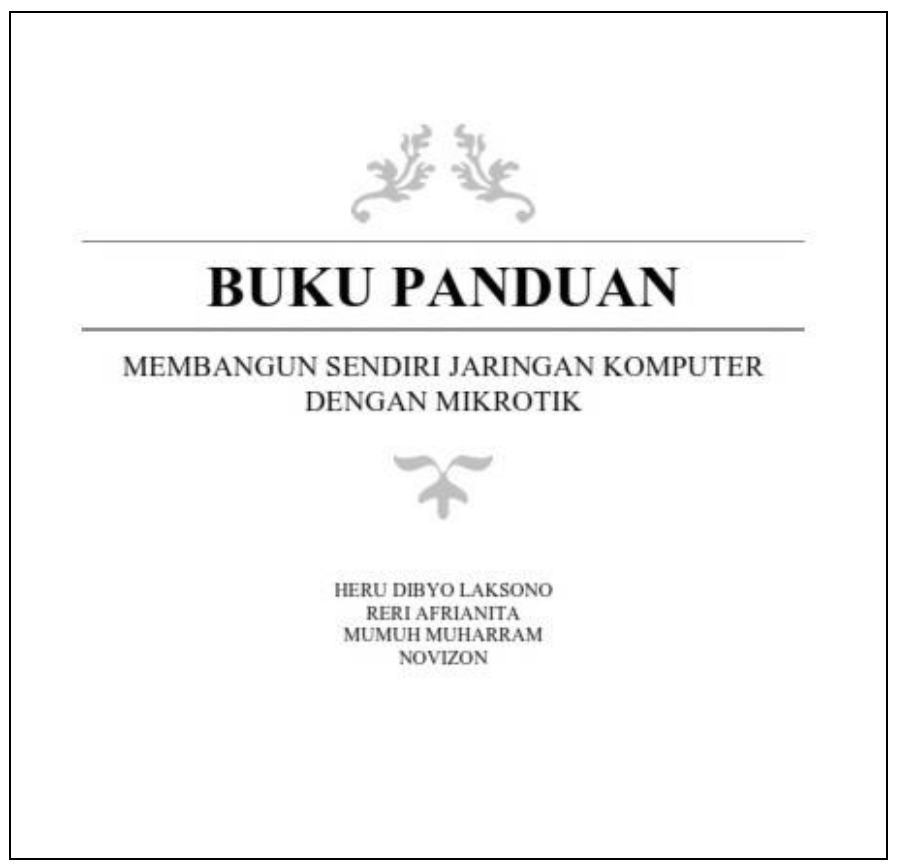

Gambar 4. Cover Buku Panduan 


\section{KESIMPULAN}

Kegiatan pelatihan dan pendampingan jaringan komputer dengan mikrotik di Pondok Pesantren Modern Terpadu Dr. Muhammad Natsir Alahan Panjang telah dilaksanakan selama 2 hari yaitu hari Sabtu dan Minggu. Materi pengetahuan tentang dasar - dasar jaringan komputer dan mikrotik diberikan pada hari pertama, diikuti dengan praktek pada hari kedua. Peserta sangat antusias dengan kegiatan ini, karena merupakan pengetahuan yang bisa langsung dipakai, namun perlu ditindaklanjuti setiap periode tertentu. Hal ini dikarenakan perkembangan teknologi jaringan komputer mengalami kemajuan yang pesat. Bagi peserta pelatihan sendiri akan memberikan manfaat terhadap peningkatan kemampuan mereka di bidang teknologi jaringan.

\section{UCAPAN TERIMA KASIH}

Terima kasih kepada Lembaga Penelitian dan Pengabdian kepada Masyarakat (LPPM) Universitas Andalas sebagai penyandang dana program kegiatan pengabdian masyarakat yang sudah dilaksanakan.

\section{DAFTAR PUSTAKA}

Haryanto, E.V. 2018. Jaringan Komputer. Jogjakarta: Andi Offset.

Kurose, J.F. 2005. Computer Networking. New York: Pearson Education.

Mukti, Y.I. 2020. Pelatihan Pembuatan Jaringan LAN di SMK 1 PGRI Pagar Alam. NGABDIMAS , 62-67.

Mulyanta, E.S. 2005. Pengenalan Protokol Jaringan Wireless Komputer. Jogjakarta: Andi Offset.

Syafrizal, M. 2020. Pengantar Jaringan Komputer. Jogkarta: Andi Offset.

Winarno, E. 2013. Membuat Sendiri Jaringan Komputer. Jakarta: Elx Media Komputindo.

Yovita, L.V., \& Irawati, I.D. 2015. Jaringan Komputer dan Data Lanjut. Jogjakarta: Andi Offset. 